\title{
A useful flap combination in wide and complex defect reconstruction of the medial canthal region: Glabellar rotation and nasolabial $\mathrm{V}-\mathrm{Y}$ advancement flaps
}

\author{
Erol Kesiktas MD, Cengiz Eser MD, Eyüphan Gencel MD, Emrah Efe Aslaner MD
}

\begin{abstract}
E Kesiktas, C Eser, E Gencel, EE Aslaner. A useful flap combination in wide and complex defect reconstruction of the medial canthal region: Glabellar rotation and nasolabial V-Y advancement flaps. Plast Surg 2015;23(2):113-115.
\end{abstract}

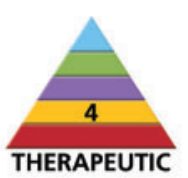

BACKGROUND: Reconstruction of medial canthal defects after tumour excision is difficult owing to the thin skin of the region and the concavity of the anatomical landmarks, which enclose complex structures such as the medial canthal ligament and the lacrimal system. Local reconstruction methods for this region include secondary healing, full-thickness skin grafts, and skin flaps from the frontal, transnasal, glabellar and upper eyelid regions. OBJECTIVE: To demonstrate a useful combination of two local flaps in wide defects of the medial canthal region.

METHODS: Between 1998 and 2012, a combination of glabellar rotation and nasolabial V-Y advancement flaps were used in 11 patients with wide complex defects after excision, including periosteum, of invasive basal cell carcinoma.

RESULTS: All patients were tumour free and underwent functional and aesthetic reconstruction of the medial canthal region. There were no major complications, and no relapses were observed.

CONCLUSION: This technique achieves good match in colour and texture, and has satisfactory results both aesthetically and functionally. In addition, donor area morbidity is minimal and surgical technique is simple.

Key Words: Glabellar flap; Medial canthal recontruction; Nasolabial flap

\author{
La combinaison utile de lambeaux pour la \\ reconstruction d'anomalies larges et complexes \\ de la région du canthus interne : une rotation \\ glabellaire et des lambeaux nasolabiaux \\ d'avancement en VY
}

\begin{abstract}
HISTORIQUE : Il est difficile de reconstruire des anomalies du canthus interne après l'excision d'une tumeur, en raison de la minceur de la peau et de la concavité des repères anatomiques, qui incluent des structures complexes comme le ligament du canthus interne et le système lacrymal. Les modes de reconstruction locale incluent la cicatrisation secondaire, les greffes de peau totales et les lambeaux cutanés des régions frontale, transnasale, glabellaire et de la paupière supérieure.

OBJECTIF : Démontrer la combinaison utile de deux lambeaux locaux pour corriger de larges anomalies de la région du canthus interne.

MÉTHODOLOGIE : Entre 1998 et 2012, 11 patients ayant de larges anomalies complexes après l'excision (incluant le périoste), d'un carcinome basocellulaire invasif, ont été soignés par une combinaison de rotation glabellaire et de lambeaux nasolabiaux d'avancement en VY.

RÉSULTATS : Les patients, qui ne présentaient plus de tumeur, ont subi une reconstruction fonctionnelle et esthétique de la région du canthus interne. Ils n'ont pas présenté de complications majeures et n'ont pas subi de récidives.

CONCLUSION : Cette technique assure une belle concordance de couleur et de texture et des résultats satisfaisants sur le plan esthétique et fonctionnel. Par ailleurs, la morbidité est minime dans la région du donneur, et la technique chirurgicale est simple.
\end{abstract}

$\mathrm{T}$ he eyelid consists of several structures that are aesthetically and functionally unique. The medial canthal region is particularly complicated anatomically owing to its thin skin and important structures such as the medial canthal ligament and lacrimal system (1). The medial canthal region is the second most common location for periorbital tumours. Wide excision to produce tumour-free margins often results in skin, soft tissue and periosteum defects, presenting a reconstruction challenge for plastic surgeons (1-7). During reconstruction, the mobile and characteristically thin skin of the eyelid must be considered as an aesthetic and functional unit $(4,8)$.

For medial canthal reconstruction, many different methods can be used such as secondary healing, full-thickness skin grafts, and local or distant flaps. When a flap is used for reconstruction, neighbouring tissue should be the first choice to achieve natural appearance, colour and tissue harmony (2,8-11). Frontal flaps, transnasal flaps, V-Y advancement flaps, myocutaneous flaps from the upper eyelid and glabellar flaps are some of the local choices that may be used in this region (4). In addition, flap combinations may be used in a situation in which a single flap is not sufficient for closure.

A combination of glabellar rotation and nasolabial V-Y advancement flaps is a useful option, both aesthetically and functionally, in complex defects after excision of basal cell carcinomas (BCCs) from the medial canthal region. We present our experience using this flap combination for reconstruction of medial canthal defects following excision of invasive BCCs.

\section{METHODS}

Between 1998 and 2012, wide tumour excision, including the periosteum, was performed in 11 patients (seven women, four men, age range 57 to 78 years, mean age 65.1 years) who had invasive tumours in the medial canthal region. Incisional biopsy results were BCC for all patients preoperatively.

All of the operations were performed under general anesthesia. The tumours, including the periosteum and with a surgical margin of $0.5 \mathrm{~cm}$, were excised to achieve a tumour-free defect. Perioperatively, confirmation of surgical margins were made by frozen-section biopsies. The defect sizes ranged between $2.5 \mathrm{~cm} \times 3 \mathrm{~cm}$ and $4 \mathrm{~cm} \times 4 \mathrm{~cm}$. Flap sizes were planned to close the defect. After the elevation of glabellar and nasolabial flaps in a random and suprafascial fashion with a length-to-width ratio of 3:1, the glabellar flap was rotated and the nasolabial flap was advanced in a V-Y manner. The donor sites were closed primarily in all of the patients (Figures 1A to 1D). Six months postoperatively, all patients were evaluated for epiphora, lagophthalmos, intercanthal distance difference and patient satisfaction. Lagophthalmos measurement was performed using a ruler to measure the distance (in $\mathrm{mm}$ ) between the upper and lower eyelid margins. The intercanthal distance difference was calculated by subtraction of the preoperative measurement of inner intercanthal distance (in $\mathrm{mm}$ ) from the postoperative measurement. Patient satisfaction was measured by assessing their responses to a two-item feedback questionnaire using a five-point

Plastic Reconstructive and Aesthetic Surgery Department, University of Cukurova Balcall Hospital, Adana, Turkey

Correspondence: Dr Erol Kesiktas, Plastic Reconstructive and Aesthetic Surgery Department, University of Cukurova Balcal Hospital,

Sariçam/Adana, Turkey. Telephone 905-05884-2021, e-mail erolkesiktas87@gmail.com 


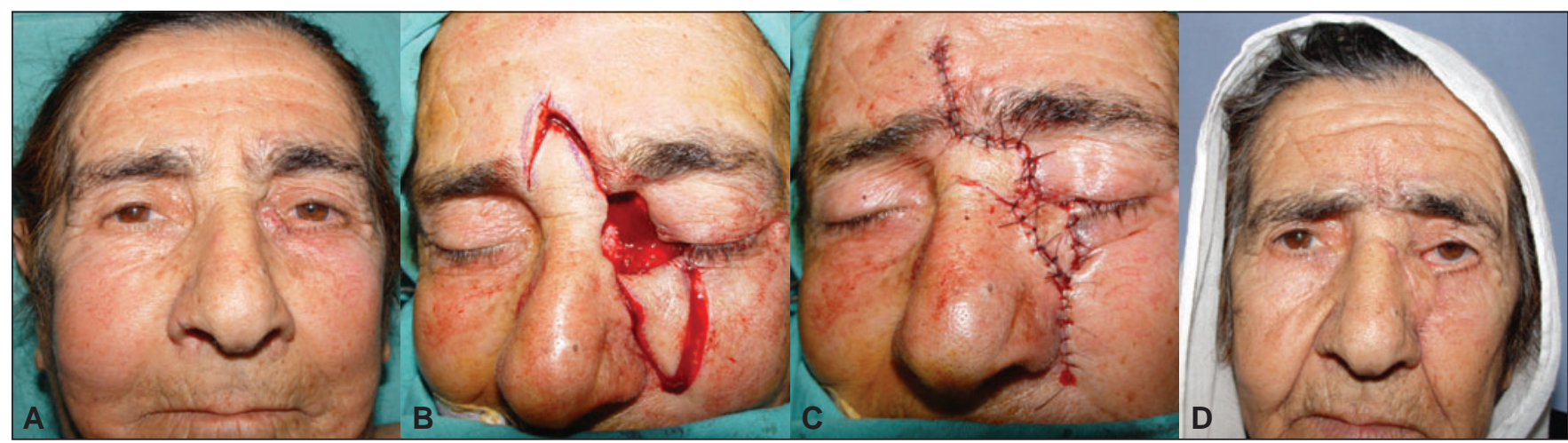

Figure 1) A Preoperative view of a patient with basal cell carcinoma on her left medial canthal region. B Perioperative view of the patient after glabellar and nasolabial flap harvesting. C Immediate postoperative view of the patient after insetting of flaps. D Postoperative photograph at 24 months follow-up

TABLE 1

Patient characteristics

\begin{tabular}{|c|c|c|c|c|c|c|c|c|c|}
\hline Patient & $\begin{array}{l}\text { Age, } \\
\text { years }\end{array}$ & Sex & Diagnosis & $\begin{array}{c}\text { Defect size, } \\
\mathrm{cm}\end{array}$ & Epiphora & Lagophthalmos, mm & $\begin{array}{l}\text { Intercanthal distance } \\
\text { difference, } \mathrm{mm}\end{array}$ & Patient satisfaction* & $\begin{array}{c}\text { Follow-up, } \\
\text { months }\end{array}$ \\
\hline 1 & 61 & Female & $\mathrm{BCC}$ & $3 \times 4$ & + & - & 2 & 4 & 11 \\
\hline 2 & 65 & Female & $\mathrm{BCC}$ & $3 \times 3.5$ & + & - & 3 & 4 & 9 \\
\hline 3 & 57 & Male & $\mathrm{BCC}$ & $4 \times 4$ & + & 2 & 2 & 4 & 36 \\
\hline 4 & 72 & Male & $\mathrm{BCC}$ & $3 \times 3.5$ & + & - & 1 & 5 & 15 \\
\hline 5 & 69 & Female & $\mathrm{BCC}$ & $3 \times 3$ & - & 1.5 & 3 & 4 & 12 \\
\hline 6 & 60 & Female & $\mathrm{BCC}$ & $3 \times 4$ & + & - & 1 & 5 & 10 \\
\hline 7 & 71 & Female & $\mathrm{BCC}$ & $3 \times 3.5$ & + & - & 1 & 5 & 24 \\
\hline 8 & 78 & Female & $\mathrm{BCC}$ & $3 \times 5$ & + & 2 & 2 & 4 & 20 \\
\hline 9 & 61 & Male & BCC & $3 \times 3$ & + & 2 & 2 & 4 & 7 \\
\hline 10 & 65 & Male & BCC & $2.5 \times 3$ & - & - & 2 & 5 & 18 \\
\hline 11 & 58 & Female & $\mathrm{BCC}$ & $3.5 \times 3$ & + & - & 2 & 4 & 9 \\
\hline
\end{tabular}

*Five-point Likert scale: 1 Poor; 2 Below average; 3 Average; 4 Above average; 5 Excellent. + Present; - Absent; BCC Basal cell carcinoma

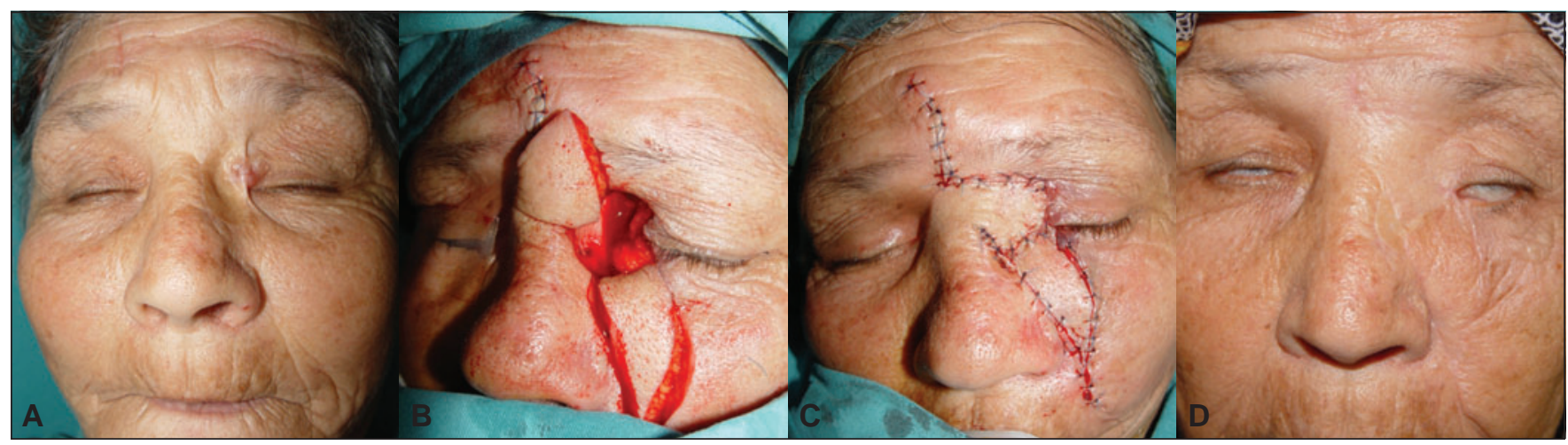

Figure 2) A Preoperative view of a patient with basal cell carcinoma on her left medial canthal region. B Perioperative view of the patient after glabellar and nasolabial flap harvesting. C Immediate postoperative view of the patient after insetting of flaps. D Postoperative photograph at 36 months follow-up

Likert scale (Table 1). Patients were followed for between seven and 36 months (mean 15.5 months) (Figures 2A to 2D).

\section{RESULTS}

In the early postoperative period, periorbital ecchymosis and edema were observed but regressed and faded in eight to 10 days. There were no major complications such as flap loss or infection. In the six-month follow-up period, nine patients had epiphora, four of which developed lagophthalmos. The intercanthal distance difference was calculated to be between $1 \mathrm{~mm}$ and $3 \mathrm{~mm}$ (mean $1.9 \mathrm{~mm}$ ) six months postoperatively. In the long term, there was no cicatricial ectropion or abnormal scarring on the face. Patient satisfaction according to the five-point Likert scale was 'above average' or 'excellent' for all patients. No relapses were observed in the follow-up period.

\section{DISCUSSION}

The periorbital region consists of five areas (1): upper eyelid; lower eyelid; medial canthal region; lateral canthal region; and contiguous area. The medial canthal region is the second most common location for periorbital BCCs (5). Reconstruction after tumour excision presents a challenging problem due to critical anatomical structures such as the medial canthal tendon, lacrimal system and neurovascular structures arising from the orbit. It is also difficult to obtain tissue of appropriate colour and thickness $(1,6,7)$. Maintaining the natural concavity of the region with no distortion of the surrounding tissue, achieving symmetry, and protecting the visual field and eyelid movements without cicatricial ectropion must be considered during reconstruction $(4,5)$. 


\section{RECONSTRUCTION TECHNIQUES}

There are several techniques for reconstruction of the medial canthal region such as secondary healing, skin grafting, and skin flaps including bilobed, transnasal, V-Y advancement, myocutaneous flaps from the upper eyelid, glabellar, forehead and a combination of these flaps $(1,2,4-8)$.

\section{Secondary healing}

Secondary healing can be considered in small and superficial defects. Especially in elderly patients, healing can be achieved with contraction in approximately four to six weeks. However, overcontraction and distortion are the drawbacks of this procedure $(1,9)$.

\section{Skin grafting}

If the periosteum is intact after tumour excision, skin grafting may be used due to a vascularly rich bed. Donor site morbidity, and colour and thickness noncompliance are the drawbacks of this method. Skin grafts may also heal with distortion and hypo- or hyperpigmentation.

\section{Skin flaps}

The disadvantages of secondary healing and skin grafting make skin flaps the primary choice in the reconstruction of medial canthal region $(1,4,6,9,11)$. In elderly patients who have excess skin in the upper eyelid, an orbicularis oculi myocutaneous flap may be used for small defects. This flap cannot cover the wider defects. This flap is not recommended in most younger patients due to the frequent lack of excess skin in the upper eyelid area (9).

The bilobed flap, which is elevated from the nasal dorsum, is a good choice with regard to colour and tissue harmony but it cannot be used in wide defects (6). A forehead flap can be used to cover wider defects, but it requires a two-stage operation and it is a relatively thick flap, which may need defatting later on. A subcutaneously pedicled forehead flap can be completed in one stage but the bulging at the pedicle site is a disadvantage of this procedure (3).

The single local flaps mentioned above may be insufficient to adequately cover wide defects in the medial canthal region. For these wider defects, a combination of flaps is suggested (4). In our study, the defect sizes after wide excision including periosteum due to locally invasive BCCs ranged between $2.5 \mathrm{~cm} \times 3 \mathrm{~cm}$ and $4 \mathrm{~cm} \times 4 \mathrm{~cm}$. These defects were considered to be too wide for coverage with a single flap. Additionally, neither secondary healing nor skin grafting were considered because there was no intact periosteum. Thus, we selected a glabellar rotation and nasolabial V-Y advancement flap combination. The most important advantages of combined glabellar and nasolabial V-Y advancement flaps are a simple application of these flaps to close wide defects, colour and tissue harmony, and functionally and aesthetically satisfactory results (4).

The disadvantages of large glabellar flaps are dog-ear deformity and shortening of the distance between the eyebrows after closure of the donor area. To prevent the latter, some modifications are suggested in the literature. The Rintala flap, bilobed glabellar flap and flap in flap technique are some of the described methods (2,4-6). However, because some of the flap is used to cover the donor area in these methods, it is not possible to close large defects. A disadvantage of the nasolabial V-Y advancement flap is the possibility of cicatricial ectropion in the long term if not designed properly.
During wide tumour excisions of the medial canthal region, the medial canthal ligament and ductus nasolacrimalis may be excised, as was the case in our study. Excision of the medial canthal ligament and ductus nasolacrimalis may result in epiphora, telecanthus and lagophthalmos in the long term (10). In the present study, lagophthalmos and telecanthus were partially prevented by the superomedial suspension effect of glabellar flap. However, epiphora was unavoidable because punctal and ductal structures were excised. After long-term follow-up, patients were referred for dacryocystorhinostomy and canthoplasty if they experienced no relapses.

\section{CONCLUSION}

Medial canthal region reconstruction should be performed with local flaps considering colour and tissue match. However, in some situations, large defects cannot be closed with single flap. Hence, using the combination of nasolabial V-Y advancement flap and glabellar rotation flap is a useful alternative method for the reconstruction of large defects. Providing sufficient skin and soft tissue, matching colour and texture and obtaining satisfactory results aesthetically and functionally are the advantages of this technique. Acceptable donor site morbidity and the relatively simple surgical technique are further advantages of this flap combination for medial canthal reconstruction.

\section{REFERENCES}

1. Jelks GW, Glat PM, Jelks EB, Longaker MT. Medial canthal reconstruction using a medially based upper eyelid myocutaneous flap. Plast Reconstr Surg 2002;110:1636-43.

2. Onishi K, Maruyama Y, Okada E, Ogino A. Medial canthal reconstruction with glabellar combined rintala flaps. Plast Reconstr Surg 2007;119:537-41.

3. Karşıdağ S, Sacak B, Bayraktaroğlu S, et al. A novel approach for the reconstruction of medial canthal and nasal dorsal defects: Frontal hairline island flap. J Craniofac Surg 2008;19:1653-57.

4. Yıldırım S, Aköz T, Akan M, et al. The use of combined nasolabial V-Y advancement and glabellar flaps for large medial canthal defects. Dermatol Surg 2001;27:215-18.

5. Turgut G, Ozcan A, Yeşiloğlu N, Baş L. A new glabellar flap modification for the reconstruction of medial canthal and nasal dorsal defects: 'Flap in Flap' technique. J Craniofac Surg 2009;20:198-200.

6. Mehta JS, Olver JM. Infraglabellar transnasal bilobed flap in the reconstruction of medial canthal defects. Arch Opthalmol 2006;124:111-5.

7. Behroozan D, Goldberg L. Upper eyelid rotation flap for reconstruction of medial canthal defects. J Am Acad Dermatol 2005;53:635-8.

8. Berry MG, Fernandes AE. Triple-flap medial canthal reconstruction. Can J Plast Surg 2008;16:170-2.

9. Stagno d'Alcontres F, D'Amico E, Colonna MR, Quatra F, Lupo F. The orbicularis oculi myocutaneus flap in the repair of the medial canthal region. A new strategy for canthal resurfacing. Br J Plast Surg 2004;57:540-2.

10. Dollfus H, Verloes A. Dysmorphology and the orbital region: A practical clinical approach. Surv Ophthalmol 2004;49:548-61.

11. Boustany A, Ghareeb P, McClellan WT. Forehead reconstruction using a modified dual-plane A to T flap. Can J Plast Surg 2012;20:251-4. 